\title{
PENGEMBANGAN KURIKULUM SEBAGAI SOLUSI ATAS TIDAK ADANYA KORELASI ANTARA IPK DENGAN KESADARAN PANGGILAN DAN PELAYANAN PADA MAHASISWA SEKOLAH THEOLOGIA Pdt. Ivan Th. J. Weismann, S.Th., M.Hum.
}

\section{Latar Belakang Masalah}

Agar perubahan terjadi di tingkat dasar maka "budaya masyarakat beriman" harus ditransformasikan. Orang Kristen harus memiliki identitas pribadi yang kuat di dalam Kristus sebelum menjalankan misi panggilan Allah (Carr, 1986: 24). Salah satu kewajiban pendidikan teologia ialah memfasilitasi proses tersebut yaitu, melalui proses tahap pengembangan kognisi dan kesadaran (moral dan iman)

Berdasarkan pengamatan di lapangan dan dilihat dari perspektif pendidikan, sekolah teologi formal ternyata memiliki beberapa kelemahan, sehingga kesulitan memfasilitasi proses pengembangan kognisi dan kesadaran untuk menghasilkan rohaniawan yang siap menjalankan misi pangilan Allah itu. W. C. Weld menyimpulkan kelemahan tersebut diantaranya ialah: sekolah teologi tidak mampu memasok rohaniawan yang dibutuhkan gereja. Para lulusannya ketika melayani di gereja tidak dapat meunjukkan dirinya sebagai seorang yang berjiwa gembala yang dibutuhkan oleh gereja. Walaupun para pendeta telah diperlengkapi baik secara akademis, persiapan itu tidak memampukannya untuk memberi sumbangsih bagi kehidupan spiritual dan teologi jemaat yang dilayaninya (Pilimon, 2000: 53-54). Menurut Weld kelemahan-kelemahan tindakan dan prestasi kerja para rohaniawan itu dapat dikembalikan sebagai kelemahan penyelenggaraan pendidikan sekolah teologia formal, sementara seminari acapkali menegaskan bahwa itu bukanlah kesalahan dari pihaknya (Pilimon, 2000: 54).

Pandangan Weld tersebut sangat menggelisahkan penulis sehingga mendorong penulis melakukan penelitian untuk mengetahui seberapa jauh kebenaran pandangan Weld itu khususnya bahwa perlengkapan secara akademis tidak memberi kemampuan bagi para pendeta untuk memberi sumbangsih bagi kehidupan spiritual dan teologi jemaat yang dilayaninya, serta kelemahan tersebut dapat dikembalikan pada penyelenggara pendidikan sekolah teologi formal.

Melalui tulisan ini penulis mencoba menjawab persoalan tersebut dengan melakukan penelitian tentang Bagaimana korelasi antara perlengkapan akademis dalam hal ini Indeks Prestasi Kumulatif (IPK) dengan kesadaran panggilan dan pelayanan.

\section{Tujuan Penulisan}

1. Inventarisasi data IPK dan kesadaran panggilan dan pelayanan.

2. Uji statistik atas inventarisasi data.

3. Evaluasi kritis atas hasil analisa uji statistik.

4. mendeskripsikan pengembangan kurikulum 


\section{Tinjauan Pustaka}

Berikut ini adalah gambaran hasil penelitian Pendidikan Teologi di Rumania oleh I. Bria antara tahun 1942 sampai 1994, khususnya setelah lepas dari kekuasaan komunis pada tahun 1989. Hasil penelitian menunjukkan bahwa kompetensi kepemimpinan rohaniawan yang sangat dinilai tinggi oleh jemaat adalah kompetensi berkhotbah dan kompetensi di bawahnya yang tidak begitu utama adalah ketrampilan penggembalaan dengan menekankan etika personal, komitmen pada persekutuan dan relasi sosial, sedangkan pemahaman Alkitab yang lebih medalam kurang diperhatikan. Menurut Bria, jika pendidikan teologi tersebut tidak diperbaharui, kemungkinan akan membuat pelajar seminari generasi muda apatis terhadap iman mereka (Pilimon, 2000: 56).

Selanjutnya adalah hasil kajian M. Young mengenai kritikan terhadap sekolah teologi dari berbagai sumber. Menurut Young ada dua hal (sebenarnya tiga, tetapi penulis memilih dua) yang terus-menerus menjadi sumber masalah pendidikan teologi yang menyebabkan orang-orang yang dilayani menjadi tidak puas terhadap lulusan sekolah teologi. Pertama, Kurang Bermanfaat. Mata kuliah teologi yang disajikan di sekolah teologi masing-masing diajarkan sendiri-sendiri secara terpisah, tidak dilihat, diajarkan dan tidak disatukan oleh suatu pendekatan teologis sebagai sistem keyakinan dan diajarkan lepas dari kehidupan nyata. Menurut Young, teologi harus dilihat, diajarkan dan dikembangkan sebagai titik tolak keyakinan, nilai dan motivasi. Kedua, Kurang Menyatu dari Segi Rasional Maupun dari Segi Tujuan. Hal ini terjadi, menurut Young, berkaitan dengan kurangnya kepekaan akan misi dalam sekolah teologi maupun gereja yang seharusnya menjadi tujuan pengikat dari semua mata kuliah yang diberikan sekolah teologi. Jadi bukan saja sekolah teologi memerlukan teologi misi, tetapi juga memerlukan misi teologi (Pilimon, 2000: 57-58).

Berikut ini adalah data hasil pengamatan di lapangan dari Rick Kalal, seorang penginjil gereja Eastbrook, Milwauke, Wisconsin. Menurut Kalal, gembala-gembala dari berbagai "gereja-gereja besar dan berkuasa" menyatakan bahwa mereka tidak puas dengan produk yang dihasilkan kampus Trinity Evangelical Divinity School (TEDS). Para pendeta menilai bahwa lulusan TEDS hanya bisa mengeksegesis Alkitab tetapi kurang mampu mengesegesis budaya. Para lulusan tahu membaca bahasa Yunani dan Ibrani, tetapi kurang matang dalam spiritual, ketrampilan organisasi, dan pengembalaan untuk dapat menjadi pendeta yang efektif (Pilimon,2000: 58).

Neville Carr menjelaskan karakteristik pendidkan Kristen yang efektif:

1. Harus menolong orang percaya menafsir dan merespon secara Kristiani akan Firman Allah yang akan membentuk mereka.

2. Harus bertangungjawab atas dunia siswa (kognitif, afektif, eksistensial dan praktika) dan tahap-tahap perkembangan pengetahuan, moralitas, iman dan spiritualitas.

3. Harus melengkapi orang percaya untuk tugas profetik dan kritik agar terjadi transformasi atas diri mereka sendiri, masyarakat dan budaya ke dalam rupa dan gambar Kristus.

4. Harus ada penyatuan aksi dan reflrksi (pengetahuan dan perbuatan) dalam mendukung keadilan, damai dan kasih dalam dunia.

5. Harus melengkapi orang percaya secara individual dan kolektif, untuk mendalamai pengenalan mereka akan Allah dan menggenapi kehidupan mereka sebagai umat perjanjian Allah yang merspon semua tuntutan Kerajaan Sorga.

Carr kemudian menunjukkan bahwa pada masa kini, pendidikan teologia telah menyimpang dari tanggungjawabnya: akademik telah dipisahkan dari pengalaman dan misi Kerajaan Sorga; lebih mendukung ideologi kekuasaan kaum pria; mengunci diri dalam pengetahuan picik yang tidak mau dikritik yang resisten atas perubahan. Jika semua orang 
Kristen dipangil Allah untuk mentransformasikan dunia dalam keserupaan dengan Allah, maka pendidikan teologia harus didemokratisasi. Semua orang percaya harus "mengerjakan teologia"; dan gereja harus yakin bahwa semua orang percaya memiliki akses dan perlengkapan untuk mengerjakan teologia itu (Carr, 1986: 30).

\section{Landasan Teori}

Penulisan ini mencoba melihat korelasi antara pengetahuan akademis (IPK) dengan kesadaran panggilan dan pelayanan. Kesadaran panggilan dan pelayanan di dalamnya termasuk pula kesadaran moral. Lawrence Kohlberg menjelaskan tentang korelasi kematangan kognitif (IQ) dengan kesadaran moral. Menurut Kohlberg korelasi tersebut tidak besifat hubungan satu persatu, melainkan sedemikian sehingga tingkat kematangan kognitif tertentu merupakan suatu syarat yang perlu, namun belum cukup untuk suatu tingkat tertentu dari penilaian moral. Dengan kata lain, semua anak yang sudah maju secara moral merupakan anak-anak yang cerdas, tetapi tidak semua anak cerdas telah maju secara moral (atau semua anak yang bodoh secara intelektual merupakan anak-anak yang terkebelakang secara moral, namun tidak semua anak cerdas adalah anak-anak yang sudah maju secara moral). Kematangan moral menuntut kematangan kognitif, tetapi hal itu juga menuntut ciri-ciri perkembangan lainnya. Singkatnya, pandangan Kohlberg mengandung arti bahwa ciri-ciri kognitif-struktural merupakan inti perkembangan moral, tetapi penilaian moral bukan sekedar merupakan penerapan intelegensi dalam arti pemikiran logis-teknologis terhadap berbagai situasi dan masalah moral. Baik analisis psikologis maupun analisis filosofis menyarankan bahwa semakin matang tahap pemikiran moral, semakin memadai pula tahap kognitif secara struktutral (Kohlberg, 1995: 147-148).

Neville Carr mengatakan pula bahwa tujuan pendidikan seharusnya menciptakan lingkungan bagi pelajar untuk dapat mengenal dorongan-dorongan yang membentuk dirinya dan yang menghasilkan respon pada tindakannya. Salah satu kegagalan pendidikan formal meurut John Dewey ialah gagal membuat jelas apa yang terlibat dalam mengetahui dan mempercayai suatu hal. Dewey menyesali adanya dikotomi antara informasi dan kesadaran. Informasi adalah pengetahuan yang dupayakan dan disimpan; kesadaran (hikmat) adalah mengoperasikan pengetahuan yang sesuai dengan kemampuan kapasitas untuk kehidupan yang lebih baik (Carr, 1986: 25)

\section{Kerangka Pikir dan Hipotesis}

Variabel IPK dan Variabel kesadaran panggilan dan pelayanan berkorelasi positif kuat, atau $0.5<\mathrm{r}$ hitung $\leq$ +1 , atau $r$ hitung dan $t$ hitung $>\mathrm{r}$ tabel dan $\mathrm{t}$ table.

\section{Metode Penelitian}

1. Menjalankan angket untuk mengumpulkan data tentang kesadaran panggilan dan pelayanan.

2. Mendapatkan data IPK mahasiswa dari bagian administrasi

3. Analisa statistik dengan Pengukuran Variasi, Standard Score (z), Angka Skala (T-Score), dan Metode Korelasi Pearson (Pearson Product Moment).

4. Evaluasi kritis atas hasil analisa uji statistik. 


\section{Hasil dan Pembahasan}

\section{Penjelasan tentang pengolahan data}

Peneliti membagikan angket kepada mahasiswa STTJ Makassar dengan dibantu mahasiswa yang mengikuti mata kuliah Metodologi Penelitian semester genap tahun 2005. Angket tersebut terdiri dari pertanyaanpertanyaan yang menanyakan tentang kesadaran akan panggilan dan pelayanan. Indikator kesadaran panggilan yang digunakan peneliti ialah melalui angket tersebut peneliti menanyakan tingkat keaktifan responden dalam hal penginjilan, penggem,balaan, misionaris, dan kenabian. Sedangkan indikator kesadaran pelayanan, melalui angket tersebut peneliti menanyakan tingkat keaktifan responden dalam hal memberi tumpangan, administrasi, kepemimpinan, menunjukkan kemurahan, menolong, dan memberi. Setiap jawaban atas pertanyaan itu peneliti berikan nilai. Jawaban-jawaban atas kelompok pertanyaan kesadaran akan panggilan dan kesadaran akan pelayananan, nilainya dirata-ratakan lalu dibuatkan angka standard yang disebut $\mathbf{z}$-score, dengan rumus $\mathrm{z}=\mathrm{X}-$ M/SD. X ialah angka kasar yang diketahui dari hasil rata-rata nilai dari setiap jawaban angket. M ialah mean distribusi. SD ialah standar deviasi angka kasar. SD diperoleh dengan rumus $\mathrm{SD}=\sqrt{ }\left(\sum \mathrm{X}^{2} / \mathrm{N}\right)-\left(\sum \mathrm{X}^{2} / \mathrm{N}\right)^{2}$. $\mathrm{X}$ ialah angka kasar yang diketahui dari hasil rata-rata nilai dari setiap jawaban angket. $\mathrm{N}$ ialah jumlah mahasiswa. Setelah diperoleh $\mathrm{z}$ - score peneliti kembangkan menjadi angka skala dalam bentuk $\mathbf{T}-$ Score dengan rumus $\mathrm{T}=10 \mathrm{z}$ +50 . T Score adalah angka skala yamg menggunakan mean $=50$ dan $\mathrm{SD}=10$. Dalam range $-3 \mathrm{SD}$ sampai $+3 \mathrm{SD}$ angka atau bilangan $\mathrm{T}$ akan bergerak dari 20 sampai dengan 80, tanpa bilangan-bilangan minus. Setelah diperoleh T Score dari setiap mahasiswa pada kesadaran panggilan dan kesadaran pelayanannya, lalu T Score kesadaran panggilan itu peneliti korelasikan dengan nilai IPKnya. Begitu pula T Score kesadaran palayanannya peneliti korelasikan dengan nilai IPKnya dengan menggunakan Metode Korelasi Pearson (Pearson Product Moment) dengan rumus $r$

$=\left(\mathrm{n} \sum \mathrm{XY}-\sum \mathrm{X} \sum \mathrm{Y}\right) / \sqrt{ }\left(\mathrm{n} \sum \mathrm{X}^{2}-\left(\sum \mathrm{X}\right)^{2}\right) \sqrt{ }\left(\sum \mathrm{Y}^{2}-\left(\sum \mathrm{Y}\right)^{2}\right)$. $\mathrm{n}$ ialah jumlah mahasiswa. $\mathrm{X}$ ialah variable kesadaran panggilan atau pelayanan. Y ialah variable IPK. Rumus yang lain lagi dari Metode Korelasi pearson ialah $\mathrm{t}=\mathrm{r} \sqrt{ }(\mathrm{n}-2) /\left(1-\mathrm{r}^{2}\right)$

Jika dua variable telah dikorelasikan dengan mengunakan metode korelasi Pearson maka akan diperoleh hasil-hasil sebagai berikut:

1. Korelasi Positif Kuat: kedua variable yang dicari korelasinya mempunyai sifat terkait yang searah, apabila salah satu variable cenderung untuk naik nilainya, maka variable yang lainnya pun akan naik. Ketentuannya ialah $\mathrm{r}$ hitungnya mendekati +1 atau $\mathrm{r}$ hitung $>\mathrm{t}$ table dan $\mathrm{t}$ hitung $>\mathrm{t}$ table.

2. Korelasi Negatif Kuat: kedua variable yang dicari korelasinya mempunyai sifat terikat yang berkebalikan, apabila salah sartu variable cenderung naik nilainya maka variable yang lainnya akan cenderung turun demikian pula sebaliknya. Ketentuannya ialah $\mathrm{r}$ hitungnya mendekati -1 .

3. Tidak Ada Korelasi: variable yang dicari korelasinya tidak mempunyai ikatan yang tegas, masing-masing variable cenderung untuk independen (bebas). Ketentuannya ialah $\mathrm{r}$ hitung $<\mathrm{r}$ table atau $\mathrm{t}$ hitung $<\mathrm{t}$ table.

\section{Hasil perhitungan data}

Hasil perhitungan yang diperoleh dengan metode korelasi Pearson adalah sebagai berikut: 
1. Mahasiswa angkatan 2004 dengan jumlah sampel 38 orang, korelasi IPK dengan kesadaran pelayanan $r$ hitung $=0.129, \mathrm{t}$ hitung $=0.78$. Korelasi IPK dengan kesadaran panggilan $\mathrm{r}$ hitung $=0.1788, \mathrm{t}$ hitung $=1.09$. $\mathrm{r}$ table pada taraf 0.05 dengan $\mathrm{dk} 35$ ialah 0.325 , dan $\mathrm{t}$ table pada taraf 0.05 dengan dk 30 ialah 1.697. Oleh karena semua $r$ hitung tidak ada yang mendekati +1 dan tidak ada yang $>r$ table dan juga semua $t$ hitung tidak ada yang $>$ t table maka dapat disimpulkan bahwa antara IPK dengan kesadarean pelayanan dan IPK dengan kesadaran panggilan pada mahasiswa angkatan tahun 2004 tidak ada korelasi.

2. Mahasiswa angkatan 2003 dengan jumlah sampel 33 orang, korelasi IPK dengan kesadaran pelayanan $r$ hitung $=0.157, \mathrm{t}$ hitung $=0.887$. Korelasi IPK dengan kesadaran panggilan $\mathrm{r}$ hitung $=0.159, \mathrm{t}$ hitung $=0.90 . \mathrm{r}$ table pada taraf 0.05 dengan $\mathrm{dk} 30$ ialah 0.349 , dan $\mathrm{t}$ table pada taraf 0.05 dengan $\mathrm{dk} 30$ ialah 1.697. Oleh karena semua $r$ hitung tidak ada yang mendekati +1 dan tidak yang $>\mathrm{r}$ table dan juga semua $t$ hitung tidak ada yang $>$ t table maka dapat disimpulkan bahwa antara IPK dengan kesadaran pelayanan dan IPK dengan kesadaran panggilan pada mahasiswa angkatan 2003 tidak ada korelasi

3. Mahasiswa angkatan 2002 dengan jumlah sampel 18 orang, korelasi IPK dengan kesadaran pelayanan $r$ hitung $=0.384, \mathrm{t}$ hitung $=1.664$. Korelasi IPK dengan kesadaran panggilan $\mathrm{r}$ hitung $=0.025, \mathrm{t}$ hitung $=0.099$. $\mathrm{r}$ table pada taraf 0.05 dengan dk 16 ialah 0.468 , dan t table dengan taraf 0.05 dengan dk 18 ialah 1.734 . Oleh karena semua $r$ hitung tidak ada yang mendekati +1 dan tidak ada pula yang $>r$ table dan juga semua $t$ hitung tidak ada yang $>\mathrm{t}$ table maka dapt disimpulkan bahwa antara IPK dengan kesadaran pelayanan dan IPK dengan kasadaran panggilan pada mahasiswa angktan 2002 tidak ada korelasi.

4. Mahasiswa angkatan 2001 dengan jumlah sampel 14 orang, korelasi IPK dengan kesadaran pelayanan $r$ hitung $=0.4284, \mathrm{t}$ hitung $=1.645$. Korelasi IPK dengan kesadaran panggilan $\mathrm{r}$ hitung $=0.167, \mathrm{t}$ hitung $=2.062$. $\mathrm{r}$ table pada taraf 0.05 dengan dk 12 ialah 0.532 , dan $\mathrm{t}$ table dengan taraf 0.05 dengan dk 12 ialah 1.782. Semua $r$ hitung tidak ada yang mendekayti +1 dan tidak ada yang $>$ r table, ini berarti tidak korelasi atara IPK dengan kesadaran pelayanan maupun IPK dengan kesadaran panggilan. Akan tetapi pada $\mathrm{t}$ hitung ada perbedaan. Korelasi IPK dengan kesadaran pelayanan $\mathrm{t}$ hitungnya $<\mathrm{t}$ table yang berarti tidak ada korelasi, tetapi pada korelasi IPK dengan kesadaran panggilan $t$ hitungnya $>t$ table yang berarti ada korelasi. Ini berarti antara IPK dengan Kesadaran pelayanan mahasiswa angkatan 2001 tidak ada korelasi, tetapi antara IPK dengan kesadaran panggilan mahasiswa angkatan 2001 ada korelasi.

5. Mahasiswa angkatan 2000 dengan jumlah sampel 10 orang, korelasi IPK dengan kesadaran pelayanan $r$ hitung $=0.001, \mathrm{t}$ hitung $=0.003$. Korelasi IPK dengan kesadaran panggilan $\mathrm{r}$ hitung $=0.165, \mathrm{t}$ hitung $=1.473$. $\mathrm{r}$ table pada taraf 0.05 dengan dk 8 ialah 0.632 dan t table dengan taraf 0.05 dengan dk 10 ialah 1.860. Oleh karena semua $\mathrm{r}$ hitung tidak ada yang mendekati +1 dan tidak ada yang $>\mathrm{r}$ table dan juga semua $\mathrm{t}$ hitung tidak yang $>$ t table maka dapatlah disimpulkan bahwa IPK dengan Kesadaran Pelayanan dan IPK dengan Kesadaran panggilan pada mahasiswa angkatan tahun 2000 tidak ada korelasi.

\section{Perlunya Kurikulum Berbasis Kompetensi}

IPK menurut peneliti adalah indikator bagi kurikulum. Jika IPK tidak berkorelasi dengan kesadaran akan panggilan dan pelayanan maka ini berimplikasi korelasi variable IPK dengan kesadaran pangilan dan pelayanan mahasiswa terlalu variatif, kurang keseragaman atau kurang 
berkecenderungan. Ini berarti, kurikulum pada sekolah teologia tersebut masih belum memberikan fokus atau arahan teretentu pada suatu kesadaran tertentu. Misalnya fokus hanya pada missioner, atau fokus hanya pada penggembalaan. Selain itu dalam kenyatannya, adakalanya sebuah kurikulum pendidikan teologi, lebih didominasi oleh teologi sistematik karena pimpinan pendidikan teologi atau perancang kurikulumnya itu didominasi ahli bidang studi itu. Hasil kurikulum pendidikan teologi umumnya menghasilkan mahasiswa yang hanya mampu menghafalkan bahan ceramah dosennya untuk diingat kembali pada waktu ujian. Padahal efektivitas sebuah kurikulum harus dilihat dari sejauh mana perubahan hidup dialami oleh peserta didik sebagaimana tampak dalam kehidupan dan karya pelayanannya. Dengan kata lain kurikulum yang ada masih belum dapat mengembangkan secara maksimal kesadaran panggilan dan pelayanan dalam diri mahasiswa. Untuk mengatasi persoalan ini maka kurikulum yang ada perlu dikembangkan menjadi Kurikulum Berbasis Kompetensi. Dalam Kurikulum berbasis Kompetensi itu sangat diharapkan bahwa yang dipelajari oleh mahasiswa dalam kegiatan studinya mencakup aspek pengetahuan, sikap hidup, ketrampilan dan nilai-nilai hidup pribadi dan sosial. Pembahasan mengenai kurikulum Berbasis Kompetensi ini penulis sadur dari karya Muhammad Natsir yang berjudul Konsep dan Makna Kurikulum Berbasis Kompetensi dengan Life Skill Education.

Kurikulum berbasis kompetensi (KBK) dapat diartikan sebagai suatu konsep kurikulum yang menekankan pengembangan kemampuan melakukan atau kompetensi tugas-tugas dengan standar performasi tertentu sehingga hasilnya dapat dirasakan peserta didik, berupa penguasaan terhadap seperangkat konsep tertentu. KBK diarahkan mengembangkan pengetahuan, pemahaman, kemampuan nilai, sikap, dan minat peserta didik agar dapat melakukan suatu hal untuk kemahiran, kecepatan dan keberhasilan dengan sepenuh tangung jawab.

Pendidikan berusaha mengembangkan potensi individu agar mampu berdiri sendiri. Untuk itu perlu diberi berbagai kemampuan dalam mengembangkan berbagai hal, seperti konsep, prinsip, kreativitas, tangung jawab, dan ketrampilan. Dengan kata lain, perlu mengalami perkembangan dalam aspek kognitif, afektif, dan psikomotor. Demikian pula individu sebagai mahluk sosial yang selalu berinteraksi dengan lingkungan sesamanya. Obyek sosial akan berpengaruh terhadap perkembangan individu melalui pendidikan dapat dikembangkan suatu keadaan yang seimbang antara perkembangan aspek individual dan aspek sosial.

Inovasi pendidikan di negeri maju, kini juga mengarah kepada pengembangan kecakapan hidup. Model pembelajaran terpadu (Integrated Learning) dan pembelajaran kontekstual (Contextual Teaching and Learning) merupakan model pembelajaran yang mengarah pada pengembangan kecakapan hidup (Blanchard, 2001; University of Washington, 2001). Model Pembelajaran realistik (Realistic Education) yang kini sedang berkembang juga merupakan upaya mengatur agar pendidikan sesuai dengan kebutuhan nyata peserta didik, agar hasilnya dapat diterapkan guna memecahkan dan mengatasi problem hidup yang dihadapi.

Pada model-model pembelajaran tersebut, mata pelajaran/mata diklat dipadukan atau dikaitkan satu dengan yang lain agar sesuai dengan kehidupan nyata di masyarakat. Pembelajaran dikaitkan dengan kualitas kehidupan peserta didik agar memungkinkan mereka belajar menerapkan isi mata pelajaran/mata diklat dalam pemecahan problema yang dihadapi dalam kehidupan keseharian.

Perlu diperhatikan pula mengenai evaluasi hasil belajar. Pembelajaran yang berorientasi pada pembekalan kecakapan hidup dengan pembelajaran kontekstual memerlukan model evaluasi otentik serta evaluasi dalam bentuk perilaku peserta didik dalam menerapkan apa yang dipelajari dalam kehidupan nyata. 
Kurikulum Berbasis Kompetentisi akan memberikan kecakapan untuk berani menghadapi problema hidup dan kehidupan dengan wajar tanpa tertekan, kemudian secara proaktif dan kreatif mencari serta menemukan solusi tepat sehingga mampu mengatasinya.

Aspek lain yang dikembangkan melalui KBK adalah kehidupan susila. Hanya manusialah yang dapat menghayati norma-norma dan nilai-nilai dalam kehidupannya sehingga manusia dapat menetapkan tingkah laku mana yang baik dan tingkah laku mana yang tidak baik. Aspek lain adalah kehidupan religius dalam hubungannya dengan Tuhan Yang Maha Esa dapat menghayati dan mengamalkan ajarannya sesuai dengan agamanya. Semua ini dapat terwujud melalui pendidikan, karena pendidikan adalah kehidupan. Untuk itu, kegiatan belajar harus dapat membekali peserta didik dengan kecakapan hidup (Life Skill and Life Competency).

Tujuan yang ingin dicapai ialah untuk berkembangnya potensi peserta didik agar menjadi manusia yang beriman dan bertangung jawab kepada Tuhan Yang maha Esa, berakhlak mulia, sehat, berilmu, cakap, kreatif, madiri, dan menjadi warga yang demokratis serta bertanggung jawab.

Dengan adanya pendidikan berorientasi kecakapan hidup, kurikulum tidak harus diubah atau ditambah mata pelajaran. Yang diperlukan adalah reorientasi pendidikan dari Subject Matter Oriented menjadi Life Skill Oriented. Dengan hal ini mata pelajaran dipahami sebagai alat bukan sebagai tujuan. Mata pelajaran sebagai alat untuk mengembangkan kecakapan hidup yang nantinya akan digunakan peserta didik menghadapi kehidupan nyata. Pendidikan dikatakan sesuai dengan kebutuhan kehidupan masyarakat bila hasil yang diperoleh akan berguna bagi kehidupan seseorang.

Soetopo dan Soemanto (1993:49-50) mengungkapkan bahwa: (1) kesesuaian pendidikan dengan lingkungan anak didik termasuk bahan (subject matter) hendaknya disesuaikan dengan kehidupan nyata anak didik. Contoh: sekolah yang berada di perkotaan hendaknya ditawarkan kepada anak didik mengenai hal yang aktual pula, seperti masalah polusi pabrik, arus perdagangan. Sekolah yang berada di pedesaan, kepada anak didiknya ditawarkan hal-hal yang relevan. Contoh: memperkenalkan anak didik mengenai pertanian karena daerah tersebut adalah daerah pedesaan yang subur akan pertanian atau daerah yang kaya akan perikanan, persawahan, kerajinan, dan lain-lain. (2) Keseuaian pendidikan dengan kehidupan sekarang dan kehidupan yang akan datang. Materi atau bahan yang akan diajarkan kepada anak didik hendaklah memberi manfaat untuk persiapan masa depan anak didik, karena keberadaan kurikulum di sini bersifat antisipasi dan memiliki nilai prediksi ke depan secara tajam dan dengan penuh perhitungan.

Dalam era globalisasi dan pasar bebas manusia dihadapkan pada perubahan-perubahan yang tidak menentu ibarat nelayan di lautan lepas yang dapat membahyakan jika tidak memiliki kompas. Kompas sebagai pedoman untuk menghindar dan mengurangi hambatan yang akhirnya mengakibatkan hubungan yang tidak lancar antar pendidikan dengan lapangan kerja atau one to one relationship yang akhirnya terjadi kesenjangan, karena pendidikan kita masih didominasi oleh pandangan bahwa pengetahuan sebagai perangkat fakta-fakta yang harus dihafal. Kelas masih berfokus pada guru sebagai sumber utama pengetahuan kemudian ceramah menjadi pilihan utama strategi belajar. Untuk itu diperlukan sebuah strategi belajar yang baru yang lebih memberdayakan siswa menghadapi fakta-fakta, sebuah strategi yang mendorong siswa mengkonstruksi pengetahuan yang ada di benak mereka sendiri. 
Melalui landasan filosofi konstruktifisame, Contextual Teaching Learning (CTL) dipromosikan menjadi alternatif materi belajar yang baru. Melalui CTL diharapkan belajar adalah mengalami bukan menghafal. Pengetahuan bukanlah seperangkat fakta dan konsep siap diterima tetapi sesuatu yang harus dikonstruksikan sendiri oleh siswa. Oleh sebab itu, pendidikan harus diletakkan pada empat pilar, (1) belajar mengetahui (Learning to know), (2) belajar melakukan (Learning to do), (3) belajar menjadi diri sendiri (Learning to be), (4) belajar hidup dalam kebersamaan (Learning to life together).

Proses pembelajaran tidak selalu efektif dan efisien dan hasil proses belajar mengajar tidak selalu optimal karena ada sejumlah hambatan. Oleh karena itu, guru dalam memberikan materi pelajaran hanya yang berguna dan bermanfat bagi para siswa. Materi tersebut disesuaikan dengan kebutuhan mereka akan pelajaran tersebut. Belajar seperti ini akan lebih mengutamakan penguasaan ilmu dan diyakinkan akan memberi peluang pada siswa untuk lebih kreatif dan guru lebih professional. Dengan demikian pembelajaran akan lebih bermakna di mana guru mampu menciptakan kondisi belajar yang dapat membangun kreativitas siswa untuk menguasai ilmu pengetahuan.

\section{Kesimpulan}

1. Makna dari kurikulum berbasis Kompetensi diharapkan dapat membawa mahasiswa lebih berkualitas dan memiliki kecakapan hidup atau ketrampilan hidup yang kemudian akan digunakan dalam hidup dan kehidupannya di masa-masa yang akan datang.

2. Makna Kurikulum Berbasis Kompetensi kiranya dapat memampukan mensinergikan pengetahuan yang telah didapat dengan sikap kepribadian serta ketrampilan yang dimilikinya sehingga dapat mengatasi problema hidupnya.

3. Peneliti menyadari bahwa realitas spiritual bukanlah suatu produk, juga tidak dapat digambarkan berdasarkan data-data. Esensi spiritual manusia tidak dapat didefinisikan juga tidak dapat dijelaskan dalam istilah pengembangan kognitif, tahap-tahap perkembangan kesadaran (Francis, 1987: 49). Penelitian ini dibuat dalam batasan-batasan teoretis, teologis dan pragmatis, oleh karena itu pembahasan penelitian ini tidak dimaksudkan untuk menyimpulkan bahwa terdapat batasan dalam pengembangan pengetahuan dan pengalaman religius serta keterlibatan dalam partisipasi sosial. Dengan kata lain, profesionalisme dan kematangan rohani tidak ditentukan oleh IPK, kurikulum berbasis kompetensi sekalipun, maupun segala fasilitas pendidikan teologia. Peneliti memiliki keyakinan bahwa dinamika karya supernatural Allah sangat terlibat besar dalam menghasilkan manusia yang siap menjalankan misi pangilan Allah.

\section{Saran}

1. Score kesadaran pangilan dan pelayanan hanya berdasarkan jawaban dari angket, tidak melibatkan data fakta berupa keaktifan dalam kegiatan-kegiatan ekstrakurikuler. Penelitian selanjutnya diharapkan agar membuktikan jawaban angket dengan kenyataan di lapangan diantaranya berupa keaktifan pada kegiatankegiatan ekstrakurikuler.

2. Peneliti juga menyadari bahwa data mengenai kesadaran yang diperoleh lewat angket yang dijalankan belum memadai untuk mewakili semua aspek tentang kesadaran apalagi dikaitkan dengan kesadaran sosial dan moral, untuk itu penelitian selanjutnya disarankan membuat angket motivasi dan kepribadian untuk melengkapi unsur-unsur variabel kesadaran. 
3. Inovasi dan pengembangan Kurikulum Berbasis Kompetensi dalam pendidikan teologi masih perlu pula dilakukan riset lapangan dan refleksi pengalaman untuk mengembangkannya, tidak hanya berdasarkan pendapat para ahli pendidikan dan teologi.

4. Strategi yang lebih baik dalam pengembangan kurikulum ialah kebersamaan para dosen dan mahasiswa serta alumni untuk mengevaluasi kurikulum dan pembelajaran yang sudah ditempuh, kemudian bersama-sama berunding mengusulkan pendapat bagimana melakukan pembaruan.

\section{DAFTAR PUSTAKA}

Carr, Neville, 1986, The Social Impact of Christian Theology and Pedagogy: A Plea for Change,dalam Journal of Christian Education, Papers 86, hal. 19-32, The Australian Teachers' Christian Fellowship.

Francis, Steve, 1987, The Application of Fowler's Faith Development Theory to teaching Religion in a Voluntary, dalam Journal of Christian Education, Papers 90, hal. 45-50, The Australian Teachers' Christian Fellowship.

Hadi, Sutrisno, 1979, Metodologi Research, Fakultas Psikologi Universitas Gadjah Mada, Yogyakarta.

Kohlberg, Lawrence, 1995, Tahap-tahap Perkembangan Moral, Kanisius, Yogyakarta.

Natsir, Muhammad, Konsep dan makna Kurikulum Berbasis Kompetensi dengan Life Skill Education, dalam Jurnal

Ilmiah Prospek Non Eksakta, Edisi 36, Desember 2005, KOPERTIS Wilayah IX Sulawesi, hal. 130-132.

Pilimon, Jahja Elia, 2000, Hubungan Sekolah teologi, Rohaniawan lulusannya dan gereja, dalam Veritas: Jurnal

Teologi dan Pelayanan, Vol. 1, No. 1, April 2000, hal. 53-68, SAAT, Malang

Spiegel, Muray R., 1994, Statistika edisi kedua, terj. I Nyoman Susila, Ellen Gunawan, Penerbit Erlangga, Jakarta. 